\title{
Leaf silica concentration in Serengeti grasses increases with watering but not clipping: insights from a common garden study and literature review
}

\section{Kathleen M. Quigley* and T. M. Anderson}

Department of Biology, Wake Forest University, Winston-Salem, NC, USA

\author{
Edited by: \\ Julia Cooke, University of Western \\ Sydney, Australia
}

\section{Reviewed by:}

Sue Elaine Hartley, University of York, UK

Susan Ellen Melzer, Colorado State University, USA

\section{*Correspondence:}

Kathleen M. Quigley, Department of Biology, Wake Forest University, 1834 Wake Forest Road, Winston-Salem, NC 27109, USA

e-mail:quigkm1@wfu.edu
Grasses (Poaceae) lack the complex biochemical pathways and structural defenses employed by other plant families; instead they deposit microscopic silica $\left(\mathrm{SiO}_{2}\right)$ granules in their leaf blades (i.e., phytoliths) as a putative defense strategy. Silica accumulation in grasses has generally been considered an inducible defense; other research suggests silica accumulation occurs by passive diffusion and should therefore be closely coupled with whole plant transpiration. We tested the hypothesis that grasses increase leaf silica concentration in response to artificial defoliation in a common garden study in the Serengeti ecosystem of East Africa. Additionally, a watering treatment tested the alternative hypothesis that leaf silica was largely driven by plant water status. Leaf silica content of two dominant C4 Serengeti grass species, Themeda triandra and Digitaria macroblephara, was quantified after a 10-month clipping $\times$ water experiment in which defoliation occurred approximately every 2 months and supplementary water was added every 2 weeks. Themeda had greater silica content than Digitaria, and Themeda also varied in foliar silica content according to collection site. Clipping had no significant effect on leaf silica in either species and watering significantly increased silica content of the dominant tall grass species, Themeda, but not the lawn species, Digitaria. Our data, and those collected as part of a supplementary literature review, suggest that silicon induction responses are contingent upon a combination of plant identity (i.e., species, genotype, life history limitations) and environmental factors (i.e., precipitation, soil nutrients, grazing intensity). Specifically, we propose that an interaction between plant functional type and water balance plays an especially important role in determining silica uptake and accumulation.

Keywords: grass, grazing, silica, defoliation, induced defense, herbivory, phytoliths

\section{INTRODUCTION}

Plants have two general and non-mutually exclusive adaptive strategies to cope with herbivory: tolerance and resistance (Mauricio et al., 1997). Tolerance implies the capability to survive and regrow following damage by herbivores. In contrast, resistance strategies serve to prevent or reduce damage by herbivores and may entail direct resistance via production of toxic or distasteful secondary metabolites or indirect resistance by avoiding herbivores altogether through reduced apparency (Feeny, 1976). From a resource allocation standpoint, defensive structures (i.e., spines, thorns) and phytochemicals (i.e., tannins) associated with direct herbivore resistance are costly because they require energy and nutrient resources that could otherwise be invested in growth or reproduction. Thus, while some defenses are constitutively expressed, many other plant defenses are induced only after damage is experienced as a way to reduce their costs (Agrawal and Rutter, 1998; Arimura et al., 2000; Massey et al., 2007).

Some plant groups face relatively intense or frequent herbivory and utilize both tolerance and direct resistance strategies. For example, many species of grasses (family Poaceae) experience herbivory in the form of defoliation by large-bodied mammalian grazers, resulting in frequent and significant tissue loss (Gibson,
2009). Due to rapid regrowth from a basal intercalary meristem following defoliation, grasses are highly resilient to grazing stress and are typically considered grazing "tolerators" (Stebbins, 1972; McNaughton, 1979; Oyarzabal and Oesterheld, 2009). On the other hand, grasses also utilize both secondary chemicals, e.g., phenolics (Schaller etal., 2012), and structural components, e.g., microscopic deposits of solid silica termed phytoliths (Ma and Yamaji, 2006), to deter herbivores. Evidence suggests that phytoliths have been present in grasses since their early evolution, as long ago as the Late Cretaceous (Prasad et al., 2005; Strömberg, 2011). Accumulation of silica phytoliths has been considered the main defensive strategy of grasses (Coughenour, 1985), as they can amass relatively large amounts of silica and lack chemical defenses as compared to dicotyledonous plants. However, other than grasses, silica accumulation occurs primarily in ancient plant groups such as mosses, ferns, and horsetail (Hodson et al., 2005), and this fact, along with the observation that tooth enamel is considerably harder than phytoliths (Sanson et al., 2007) raises questions about the efficacy of silica as a deterrent of large-bodied mammalian grazers. Among angiosperms, Poales (the group containing grasses) are the principal silica accumulators, with wetland Gramineae accumulating up to $15 \%$ dry 
weight silica (Epstein, 1999). Biogenic silica is assimilated when roots absorb silicic acid $\left(\mathrm{Si}(\mathrm{OH})_{4}\right)$ from soil water, and solid amorphous silica $\left(\mathrm{SiO}_{2}\right)$ bodies precipitate in target cells of the epidermis as transpiration occurs (see Rudall et al., 2014). Phytoliths leave behind a three-dimensional impression of the cells that they inhabit and, because of their diagnostic nature, are often used in paleoecological reconstruction (Piperno and Pearsall, 1998).

Both active and passive mechanisms for silica uptake have been documented within the plant kingdom; active exclusion has also been observed in dicotyledonous angiosperms (Jones and Handreck, 1969). Passive uptake allows grass roots to absorb silicon $(\mathrm{Si})$ in its aqueous form, $\mathrm{Si}(\mathrm{OH})_{4}$, from the soil solution and implies limited control over silica accumulation, with stomatal conductance largely determining foliar silica content (Sangster et al., 2001). While early researchers assumed that passive uptake, in which tissue silica concentration increases as a function of transpirational water loss (Sangster and Parry, 1970; Street, 1974), was the predominant mechanism for silica accumulation, several lines of evidence have since suggested that active uptake is also often involved. For example, specialized Si efflux transporters have been identified in rice (Ma et al., 2006, 2007), maize, and barley (Mitani et al., 2009) amongst other species, and gene expression of these transporters is positively correlated with $\mathrm{Si}$ absorption from the soil solution, implying an energetic cost associated with Si transport in these high-Si accumulators. Grass foliar silica content exhibits high intra- and interspecific variation (Hodson et al., 2005), often in ways that are correlated with disturbance regimes such as grazing and fire frequency (Melzer et al., 2009). These lines of evidence suggest that active Si transport may be an important, and prevalent, mechanism for silica accumulation within Poaceae. An active mechanism could prove especially beneficial if plants are able to respond to herbivory by increasing silica uptake and silica is an effective defense mechanism, as several studies have suggested. For example, high silica content in plant tissues interferes with digestion (Massey and Hartley, 2009), is unpalatable as forage (Gali-Muhtasib et al., 1992; Cotterill et al., 2007) and reduces growth rates of small-bodied mammals (Massey and Hartley, 2006). Consistent with the putative effects of silica on extant herbivores, paleontological research suggests that grazing Hadrosaurid dinosaurs evolved the most complex dentition known to date, at least in part due to a high silica diet (Erickson et al., 2012).

Inducible uptake of silica, via an active metabolic mechanism, may also prove advantageous for coping with several types of abiotic stress. In addition to its effects as a documented antiherbivore compound, biogenic silica is known to alleviate plant stressors such as heavy metals (Galvez et al., 1987), pathogenic pests (Fauteux et al., 2006; Heine et al., 2007), salinity (Zhu et al., 2004), high temperatures, and drought (Agarie et al., 1998). Thus, it is logical that uptake, if active, may also be inducible under particular environmental conditions. Water stress affects plants ubiquitously, and it appears that silica accumulation alleviates the deleterious effects of drought for grasses. Agricultural studies indicate that soil Si fertilization decreases stomatal conductance, and thus transpirational water loss (Street, 1974; Gao et al., 2006), and enhances the stability of rice cell membranes exposed to drought (Agarie et al., 1998).
The beneficial effects of plant biogenic silica, together with the apparently low cost of assimilating and using silica as a defense have left some to conclude that silica has largely been overlooked as a vital element for stress tolerance (Cooke and Leishman, 2011a). Our study had two goals relating to the ecological significance of plant silica. First, we aimed to quantify the response of leaf silica accumulation to interactions between water availability and defoliation in two African C4 grass species, one (Themeda triandra) a caespitose "bunch" grass and the other (Digitaria macroblephara) a short "lawn" grass. To achieve this goal we conducted a common garden study in Serengeti National Park, a grazerdominated ecosystem in East Africa, in which we manipulated defoliation and water-availability over a 10-month growing period and quantified the silica responses of our two focal species. Previous research on similar grasses from the Serengeti demonstrated that grasses are capable of up-regulated silica concentrations in response to herbivory (McNaughton and Tarrants, 1983). Consequently, we hypothesized that defoliation would induce silica uptake in our two study species. In a different study of African savanna grasses, defoliated bunch grasses exhibited greater stomatal conductance and transpiration rates than defoliated lawn grasses (Anderson et al., 2013). Following these observations, we proposed a second prediction that, if silica uptake is directly linked to transpiration rate as previously reported, the bunch grass $T$. triandra would exhibit a greater silica induction following defoliation than would the lawn grass, D. macroblephara. Moreover, if silica accumulation is tightly coupled with transpiration rates, we expected to observe increased silica accumulation under conditions of higher soil moisture. Alternatively, if no relationship between soil moisture and silica concentration was observed, this suggests that active, energy-dependent silica uptake mechanisms may predominate in these species. Finally, we explored the possibility that the silica content of grasses was driven, at least in part, by their growing environment (soils, climate, herbivory, etc.). Thus, we also tested whether the site of collection was significantly related to silica variation among grasses in our common garden study.

Our second aim was to understand the results of our study in relation to a literature review of all studies reporting defoliation effects on leaf silica concentration in grasses. Our goal here was to search for a broad ecological consensus of graminoid responses to leaf defoliation and if possible, establish generalities about grassgrazer interactions and the induction of silica plant defense.

\section{MATERIALS AND METHODS COMMON GARDEN STUDY \\ Study system}

Our study was conducted in the Serengeti ecosystem in northern Tanzania $\left(2^{\circ} 19^{\prime} 51^{\prime \prime} \mathrm{S}, 34^{\circ} 50^{\prime} 0^{\prime \prime} \mathrm{E}\right)$. Serengeti is characterized by Acacia-Commiphora dominated savanna vegetation in the north and west of the ecosystem and edaphic grassland on volcanic soils in the Serengeti plains in the southeast (White, 1983). A rain-shadow created by the volcanic highlands to the south and east of Serengeti creates a relatively strong precipitation gradient, in which rainfall decreases from $>1100 \mathrm{~mm}$ yr-1 in the northwest near the shores of Lake Victoria to $\sim 600 \mathrm{~mm}$ yr-1 in the Serengeti plains at the base of the Ngorongoro crater in 


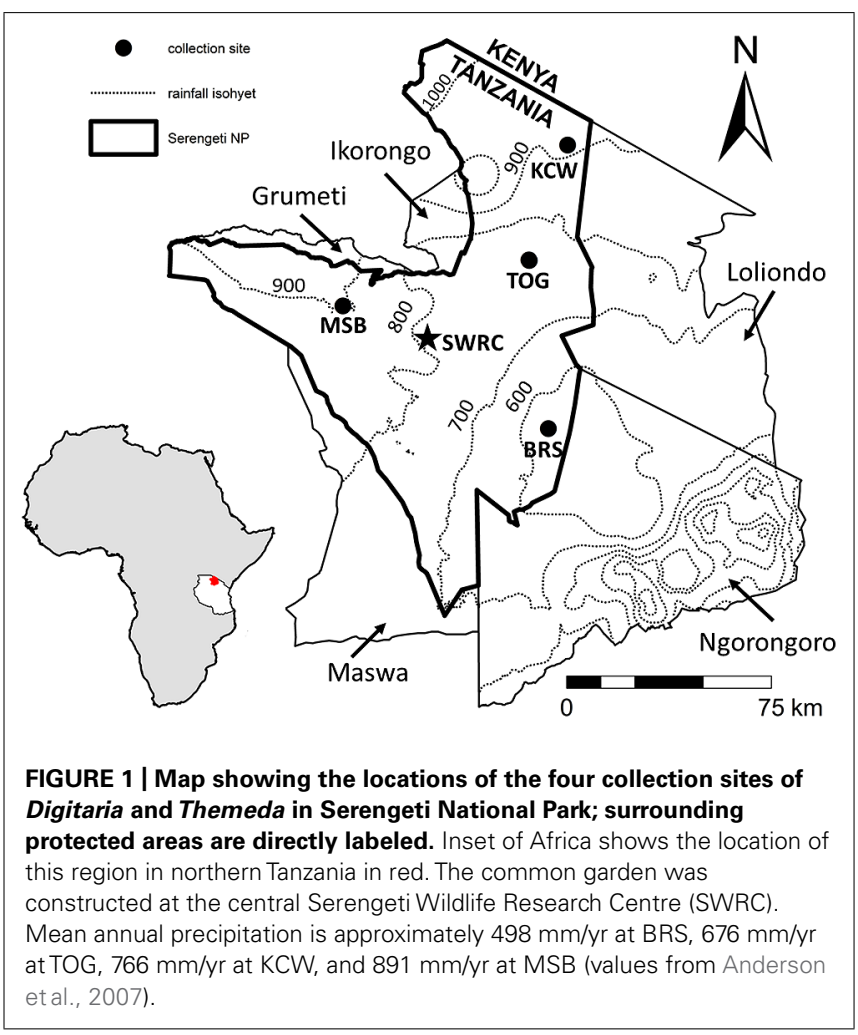

the southeast (Figure 1). Rainfall is highly seasonal and typically falls in two characteristic phases: the short rains, occurring from November-December, and the long rains, occurring from February-May (Anderson et al., 2007). The soils of the plains are heavily influenced by recent $(\sim 20,000-1,500$ ya) volcanic activity and are highly porous with an underlying calcium carbonate hardpan, resulting in highly saline and alkaline soils with poor moisture retention (Anderson and Talbot, 1965; de Wit, 1978). Interestingly, recent eruptions of nearby volcano Oldoinyo Lengai, which continue to enrich soils in the plains with ash, are of natrocarbonatite origin, meaning that, in addition to being highly enriched in potassium and sodium carbonates, they are extremely depleted of silica (Gittins, 1998; Keller et al., 2010). In contrast, the woodlands to the north are derived from granitic and quartzite parent material, while the western regions of the park are characterized by red clays (Ultisols) and black cotton soils (Vertisols) resulting from alluvial processes associated with Lake Victoria (Jager, 1982).

Serengeti is a "model" grazing ecosystem: massive herds of migratory zebra (Equus quagga boehmi) and wildebeest (Connochaetes taurinus) exert strong defoliation effects on the grasses that dominate the herbaceous layer. However, the frequency and intensity of herbivory changes along the rainfall gradient, with the most frequent and intense herbivory occurring in the Serengeti plains and decreasing with rainfall. Other significant herbivore species in Serengeti include Thomson's gazelle (Eudorcas thomsonii), which also migrate, and several non-migratory herbivores such as Grant's gazelle (Nanger granti), hartebeest (Alcelaphus buselaphus), and topi (Damaliscus korrigum). Running counter to the gradient in herbivory is an opposing gradient in fire frequency and intensity created by the tall, highly flammable, bunch grasses in the north and the procumbent, grazing tolerant grasses in the plains to the southeast that rarely burn due to their low aboveground biomass (Anderson et al., 2012). The two most dominant herbaceous species in Serengeti, in terms of both biomass and frequency, are the grasses T. triandra, a tall, caespitose bunch grass, and D. macroblephara, a short-stature, grazing tolerant lawn grass.

\section{Experimental design}

In of June 2008, multiple individuals of T. triandra and D. macroblephara, were collected from four grassland sites spanning the ecosystem's soil and rainfall gradients and transplanted into a common garden constructed at the Serengeti Wildlife Research Centre (SWRC; Figure 1). D. macroblephara was collected from Barafu (BRS) in the southeastern plains, T. triandra was collected from Klein's camp (KCW) in the northern corridor, and both species were collected from the Togoro plains (TOG) and Musabi plains (MSB). Grasses were planted in three replicate blocks; each block consisted of a $6 \times 9 \mathrm{~m}$ fenced area cleared of all vegetation and included six $2 \times 2 \mathrm{~m}$ equally spaced plots. Three randomly selected individuals of T. triandra and D. macroblephara (one from each collection site) were planted in each plot. Mean \pm SE tiller number of initial D. macroblephara individuals was $13.59 \pm 0.67$, and T. triandra transplants had a mean $\pm \mathrm{SD}=9.08 \pm 0.74$ tillers. Plots were randomly assigned to one of the six combinations of clipping (two levels: clipped and unclipped) and watering (three levels: high, ambient and low). Water was manipulated by diverting rainfall with five $25 \mathrm{~cm}$ strips of clear plastic roof material placed across the plots at $\sim 6 \mathrm{~cm}$ height and slanted slightly to promote water runoff; the treatments were designed to intercept approximately $50 \%$ of ambient rainfall. Grasses were planted between the roof strips and at least $45 \mathrm{~cm}$ from the nearest grass to provide room for growth and to prevent light competition. To control for any potential effects of the roofing material, all plots were overlaid by the roofing material but holes were drilled in the high and ambient treatments so that no water was diverted and all rainwater reached the plot. Rainfall was collected, and the high water treatment was augmented with an amount that totaled $\sim 150 \%$ of ambient every 2 weeks. Rainfall at SWRC is approximately $700 \mathrm{~mm} \mathrm{yr}^{-1}$ and the high water treatment was augmented to approximately $1000 \mathrm{~mm} \mathrm{yr}^{-1}$. Soil moisture at a depth of $12 \mathrm{~cm}$ was estimated via time-domain reflectometry monthly in each plot with a FieldScout TDR 100 (Spectrum Inc.; Aurora, IL, USA). In the clipping treatment, plants were defoliated to approximately $50 \%$ of their aboveground biomass every 2 months. Clipped biomass was dried, weighed, and summed with harvested biomass to arrive at a final biomass for clipped plants. Unclipped plants were not defoliated throughout the entire duration of the experiment. Plants were grown in the common garden for 10 months, until they were harvested in April 2009. All plants still alive at the harvest were separated into above- and belowground fractions; the aboveground fraction was further separated into leaf and stem. All plant material was dried and weighed in the lab at SWRC; leaf fractions were transported to the US, ground in a Cyclone sample mill (UDY corp.; Fort Collins, CO, USA) and stored until they were analyzed for leaf silica at Wake Forest University. 


\section{Biogenic silica quantification}

Silicon content of leaf tissue was quantified by plasma spectroscopy (ICP-OES) after autoclave-induced digestion (AID) following the methods of Kraska and Breitenbeck (2010; modified from Elliott and Snyder, 1991). Briefly, $100 \mathrm{mg}$ of dried, ground sample was wetted with 1-octanol in a $50 \mathrm{ml}$ vortex tube. Next, $2 \mathrm{~mL}$ of $50 \% \mathrm{H}_{2} \mathrm{O}_{2}$ and $3.5 \mathrm{~mL}$ of $50 \% \mathrm{NaOH}$ were added. Samples were vortexed several times, until the reaction ceased, and autoclaved loosely capped at $121^{\circ} \mathrm{C}(20 \mathrm{psi})$ for one hour. Deionized water was added to $50 \mathrm{~mL}$. Samples were brought to acidic $\mathrm{pH}$ using concentrated $\mathrm{HCl}$, and diluted 1:10 in deionized water before analyzing by ICP-OES. Si content of samples was calculated by fitting peak intensity at $251 \mathrm{~nm}$ to a standard curve $\left(0.1-10 \mathrm{ppm} \mathrm{Si} ; r^{2} \geq 0.998\right)$. The standard curve was validated with a reference material of Schizachyrium scoparium $(14 \mathrm{~g} / \mathrm{kg}$ $\mathrm{Si})$. Si values were converted to silica $\left(\mathrm{SiO}_{2}\right)$ content by dividing by a conversion factor of 0.4674 , since this more commonly reported value represents biogenic silica (phytolith) content of plant tissue.

\section{Statistical analysis}

A major goal of our statistical analysis was to understand how defoliation, water addition and their interaction, influenced leaf silica concentration in these two dominant Serengeti grasses. Therefore, we used linear mixed effect (LME) models to test the effects of species, clipping, and water on foliar silica accumulation. The model included species, clipping, and water as fixed factors, while block was included as a random effect to account for the spatial design. Analysis was performed using the lmer function in lme4 package of $\mathrm{R}$ statistical environment version 2.11.1 (Bates et al., 2014; R Development Core Team, 2014), with the original model structure: $\operatorname{lmer}(\mathrm{SiO} 2 \sim$ species * clip * water $+(1$ l block $))$, where "species* clip*water" represents the three-way fixed interaction effect and "(1l block)" represents the random intercepts that are estimated for each block. The function "step" from the $\mathrm{R}$ package lmerTest was used to simplify the model so that only significant fixed effects remained in the model, and pairwise contrasts for individual treatment effects were subsequently calculated using the "ghlt" command and a Tukey's test from the R package multcomp (Hothorn et al., 2008).

A second model was employed to explore the extent to which collection site could explain variation in foliar silica content for both species. Because we did not have sufficient replication of individual grasses at the site level, we could not explore the effects of site in a full model crossed with our other treatments. Consequently, we used a reduced statistical model to explore the main effects of site on leaf silica for each individual species averaged over all levels of water and defoliation. The model we employed for each species separately was: $\operatorname{lmer}(\mathrm{SiO} 2 \sim$ site $+(1$ l block $))$. Model simplification was again conducted via the "step" function in $\mathrm{R}$.

Finally, soil moisture was statistically compared across treatments using a model with water as a fixed effect and time and block as random effects using the lmer function in lme4 package of R as described above; the "ghlt" command from the R package multcomp was used to conduct a Tukey's post hoc comparison of means.

\section{LITERATURE REVIEW}

In order to identify general trends in plant response to defoliation, we conducted an extensive search of primary literature sources to identify studies which provided data on silica content of Poales under both control and defoliation treatments. We used Google Scholar and Web of Science to identify appropriate primary research articles by using combinations of search terms such as "clipping," "grazing," "defoliation," “silica," and "phytolith." Within the order Poales, defoliation studies were only identified for grasses, so the final literature review is limited to Poaceae. We restricted our search to studies containing species-specific silica values in order to avoid the potential confounding effects of differing community composition on bulk, plot level silica content. These studies included laboratory studies and field studies in which grazing was experimentally prevented by herbivore exclosures. Grazing studies encompassed insect, small mammal, and large mammal herbivory, and the intensity of defoliation varied within and among studies (see Discussion). Species-specific $\mathrm{Si}$ values were converted to $\mathrm{SiO}_{2}$ when necessary, assigned a unique identifier, and plotted as the log ratio normalized difference between defoliated and non-defoliated plants at the species level. Studies were then organized by defoliation method and grazer type and assigned to a general defoliation response category to facilitate interpretation of the silica response. Those cases with $a \geq 20 \%$ increase in silica following defoliation were assigned a " + ," those which decreased $\geq 20 \%$ were assigned a " - ," and those exhibiting less than a $20 \%$ relative change in silica content were assigned a " $0 . "$

\section{RESULTS \\ SERENGETI COMMON GARDEN}

Mean \pm SE soil moisture values were $11.1 \pm 1.6 \%$ for the high, $9.8 \pm 1.5 \%$ for the ambient and $9.7 \pm 1.5 \%$ for the low watering treatment. Post hoc statistical comparisons with a Tukey's test demonstrated that the low and ambient water treatments were not statistically different from one another (difference $=-0.1$, $z=-0.26, p=0.96$ ), but that the high water treatment was statistically greater than the low (difference $=1.4, z=-2.9, p=0.007$ ) and ambient (difference $=1.3, z=2.73, p=0.01$ ) treatments. Therefore, the ambient and low water treatments are combined for the remainder of the manuscript (referred to as "ambient" from here onward) and compared to the high water treatment in all analyses of watering effects.

Both the bunch-grass T. triandra and lawn-grass D. macroblephara were relatively high Si-accumulators: T. triandra had a mean $\pm \mathrm{SE}$ foliar $\mathrm{SiO}_{2}$ content of $3.7 \pm 0.25 \% \mathrm{dw}(n=20)$, while D. macroblephara had a mean $\pm \mathrm{SE} \mathrm{SiO}_{2}$ of $2.7 \pm 0.10 \%$ $(n=41)$. Neither species showed a significant response to clipping as a main effect ( $p=0.976)$ or as an interaction effect when clipping was crossed with watering level ( $p=0.453$; Figure 2). However, there was a significant species by watering interaction effect ( $p<0.05$, Supplementary Table S1) indicating that leaf silica concentrations of the two species differed in response to the watering treatment. This result arose because individuals of $T$. triandra that were watered had a higher leaf silica concentration $(4.4 \pm 0.3 \%)$ compared to those T. triandra plants that were maintained at ambient soil moisture levels ( $3.3 \pm 0.3 \%)$. In contrast, no 


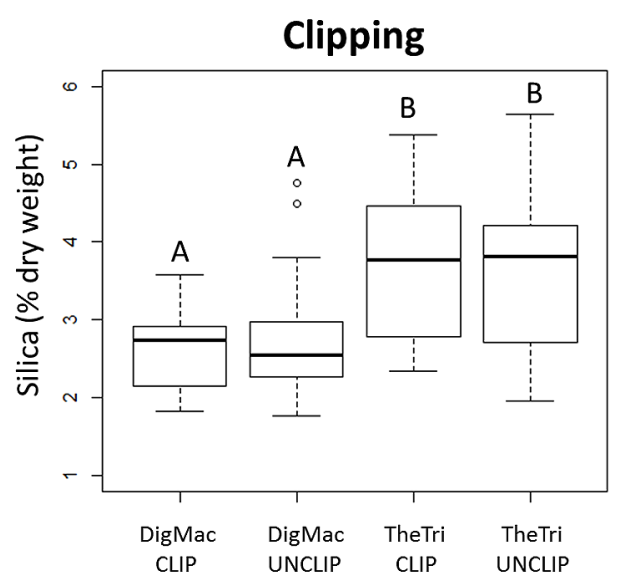

FIGURE 2 | Silica content of Digitaria macroblephara (DigMac) and Themeda triandra (TheTri) leaves as affected by defoliation and watering treatments. Defoliated individuals were clipped to $50 \%$ of maximum height bi-monthly a total of four times. High water treatment

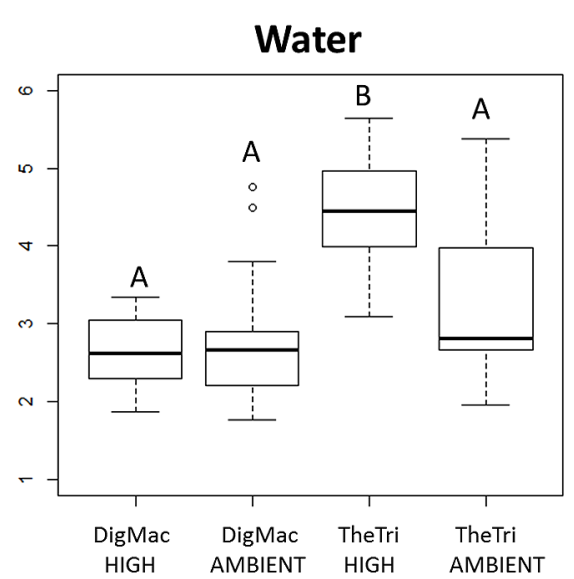

individuals received approximately $150 \%$ of ambient rainfall, and ambient treatment represents low and ambient water groups pooled (see Materials and Methods). Groups which differ significantly are indicated by a letter change. significant change in $\mathrm{SiO}_{2}$ content was observed between watering treatments for D. macroblephara (Figure 2).

In the second analysis, in which the statistical model included the main effects of plant collection site for each species separately, D. macroblephara exhibited considerable within-site variability and consequently no statistically significant differences across sites. In contrast, the $\mathrm{SiO}_{2}$ content of $T$. triandra plants varied significantly among sites (Figure 3; see Figure 1 for sites): Silica was lowest for plants collected from TOG (mean $\pm \mathrm{SE}=2.67 \pm 0.63 \%$ ), intermediate for plants from $\mathrm{MSB}$ (mean $\pm \mathrm{SE}=3.97 \pm 0.55 \%$ ), and highest for plants from $\mathrm{KCW}$ (mean $\pm \mathrm{SE}=4.18 \pm 0.53 \%$ ). Independent contrasts indicated that grasses from the low rainfall site TOG

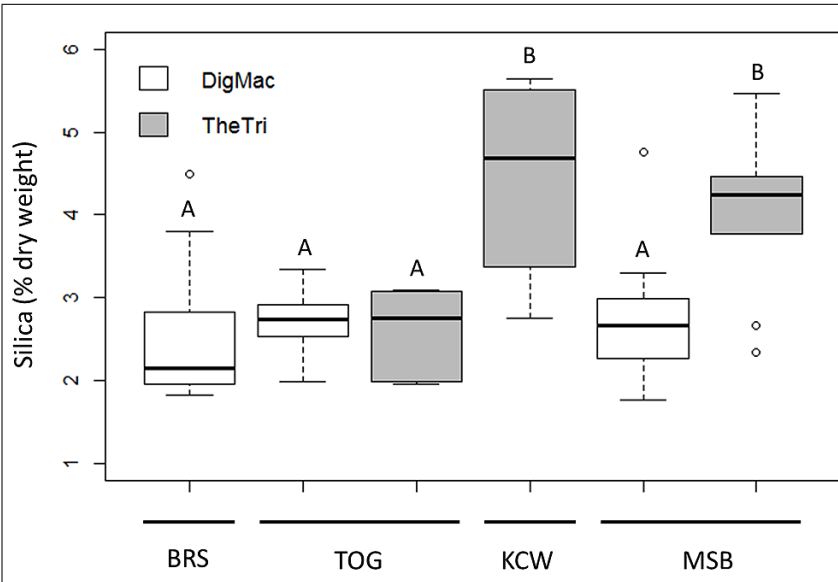

FIGURE 3 | Foliar silica content of each species in relation to plant collection sites. Both species were collected at the intermediate sites, MSB and TOG. Themeda (TheTri) does not occur at the shortgrass plains site BRS, and Digitaria (DigMac) does not occur at KCW in the northern woodlands. Sites are arranged in order of increasing mean annual precipitation: $\mathrm{BRS}=498 \mathrm{~mm} / \mathrm{yr}$, TOG $=676 \mathrm{~mm} / \mathrm{yr}, \mathrm{KCW}=766 \mathrm{~mm} / \mathrm{yr}$, MSB $=891 \mathrm{~mm} / \mathrm{yr}$. accumulated significantly less silica than those collected from MSB (difference $=-1.30, z=-2.822, p=0.005$ ) and KCW (difference $=-1.51, z=-2.408, p=0.016$ ).

\section{LITERATURE REVIEW}

We identified 11 studies conducted from 1974-present which recorded species-specific silica induction under control and defoliation treatments. These studies represented 34 "cases" of potential silica induction for 15 different grass species (Supplementary Table S2). Due to the limited number of studies conducted and lack of species-specific replication, we could not employ meta-analytical statistical approaches; instead, general responses were considered and interpreted. Eleven of fifteen species surveyed are C3, and all are perennials, except for Poa annua. Silica content of surveyed species ranged from $<0.5 \%$ dry weight (nondefoliated Anthoxanthum odoratum) to $>7 \%$ (grazed Pascopyrum smithii, Deschampsia cespitosa, and Eustachys paspaloides). To avoid pseudoreplication, we reported silica values for seasonal or site-level maxima for the three studies which reported multiple species-specific responses to the same defoliation method (Brizuela and Detling, 1986; Cid et al., 1990; Banuelos and Obeso, 2000). The majority of studies surveyed suggest that plants are able to respond to defoliation by altering their silica uptake, and indeed we observed an overall trend of silica induction following defoliation (Figure 4). Despite this general trend, several studies found no significant change in silica content of defoliated grasses, defined here as less than a $20 \%$ change in foliar silica content in either direction. The literature review revealed substantial variation in the silica responses of the different species studied. For example, the C3 grass Festuca increased silica content more than $350 \%$ in response to herbivory by voles (Massey et al., 2007), while silica content of Pascopyrum decreased by approximately 50\% following clipping (Cid et al., 1990). In general, the magnitude of induced silica uptake was greater under natural defoliation (i.e., grazing) than for mechanical clipping. Further, the magnitude of silica increase when defoliation stimulated uptake 


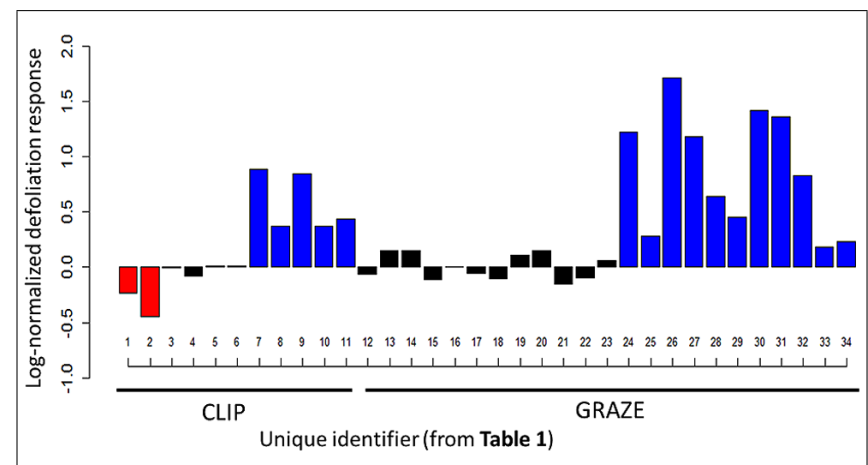

FIGURE 4 | Log-normal change in foliar silica content of defoliated grasses identified in the literature review. Blue bars indicate $a \geq 20 \%$ increase in silica following defoliation, red bars indicate $a \geq 20 \%$ decrease, and black bars indicate $<20 \%$ change in either direction. Individual responses are arranged according to unique identifiers from Supplemenatry Table S2; Unique identifiers 1-11 represent clipping studies, and 12-34 represent grazing studies.

much greater than the decrease in silica levels observed in the two studies in which clipping triggered down regulation of silica levels.

\section{DISCUSSION}

\section{VARIATION IN SILICA BETWEEN Themeda AND Digitaria}

Both species documented in this study were within the typical silica range for dryland grasses, but Themeda had significantly greater silica content than Digitaria. These two species have different suites of anatomical and physiological traits and may be considered distinct graminoid functional types (Coughenour, 1985; Diaz and Cabido, 1997). Lawn grasses, such as Digitaria, exhibit clonal, stoloniferous growth; their prostrate growth form allows them to reduce tissue loss to herbivores while quickly spreading horizontally to form lawns under high soil fertility (Cromsigt and Olff, 2008). In contrast, the higher lignin content of tall, dense, and slow-growing bunch grass species, like Themeda, makes them less palatable to herbivores than lawn grasses (Sinclair and Norton-Griffiths, 1979). Thus, as a consequence of their different life history strategies, it is not surprising that these two species differ in the degree to which silica accumulates in their leaves.

As a documented growth promoter (McNaughton et al., 1985; Isa et al., 2010) and metabolically "cheap" structural substitute for carbon-based compounds such as lignin (Raven, 1983; Cooke and Leishman, 2011a), silica deposition may provide an alternative mechanism for accelerated growth which would prove especially beneficial for bunch grasses. The increased growth rates that result from silica accumulation may substantially improve light interception of slow-growing species which primarily compete for sunlight (Ando et al., 2002). This idea is further supported by a positive correlation between leaf length and silica content observed in Spartina (Querné et al., 2012), again supporting the idea that silica allows improved growth without requiring significant carbon investment (Cooke and Leishman, 2012). Further, slow-growing bunch grasses display greater leaf mass per area, LMA, (Fynn et al., 2011) and leaf dry matter content, LDMC,
(Anderson et al., 2013) than fast-growing lawn species, indicating a greater relative investment in dry matter. The worldwide leaf economic spectrum (Wright et al., 2004) predicts a strong positive correlation between dry matter investment and leaf longevity, suggesting that, based on their higher LMA, bunchgrass species likely also have leaves of greater longevity than lawn-grass species. Thus, it may be beneficial for relatively longlived bunch grasses to invest in immobile phytoliths (Endara and Coley, 2011) which allow for rapid augmentation of cell structure of C-limited species under intense light competition. On the other hand, recent research revealed a negative correlation between leaf lifespan and Si concentration when considering a broad range of plant functional types (Cooke and Leishman, 2011b). The reasons for differential responses to defoliation and high interspecific variation in this qualitatively ubiquitous defense within Poaceae remain unclear. Here we focused on two species representing extremes of each of the two grass growth forms (bunch, lawn); greater sampling from along the gradient of short to tall grasses is needed to better understand the influence of these contrasting physiological forms on silica accumulation.

\section{DEFOLIATION RESPONSE}

Contrary to our initial predictions, clipping did not result in silica induction for either the lawn or bunch grass species, with nearly identical mean silica content observed for defoliated and non-defoliated individuals. There are several possible explanations for the lack of silica induction observed in our Serengeti common garden study. First, the frequency and/or intensity of defoliation may not have been great enough to elicit a response. For example, in the Serengeti plains, more than 1 million migratory ungulates are present in dense herds during the wet season, and localized grazing "hotspots" support dense spatially and temporally stable grazer communities that inflict especially frequent and intense herbivory on plant communities (Holdo et al., 2009; Anderson et al., 2010). Our literature review further corroborates this notion. For example, a laboratory study by Massey et al. (2007) revealed that a single defoliation event did not induce silica uptake, while repeated defoliation by herbivores (16 events total) significantly increased silica content of ryegrass and fescue, revealing the importance of both frequency and duration of defoliation. Extent of tissue removal ( $5 \%$ vs. $25 \%$ ) is also proven to affect both induction and relaxation of silica response, demonstrating a threshold effect required for induction (Reynolds et al., 2012). In our study, grasses were defoliated on a bi-monthly basis, four times total. For at least certain areas of Serengeti, this may be lower than levels of natural grazing intensity due to Serengeti's rich herbivore fauna.

In addition, manual defoliation (i.e., clipping) likely does not elicit the same response as natural grazing under laboratory or field conditions, a well-known effect with respect to induced defenses. Our literature review revealed that clipping and grazing both resulted in silica induction in $~ 50 \%$ of the studies ( 5 of 11 clipping cases, 12 of 23 grazing cases), but the magnitude of this response was much greater under grazing defoliation, as illustrated in Figure 4. Among grazing studies, silica induction was observed in response to insect, small mammal, and large mammal grazing. 
We propose that clipping may not be sufficient to represent both the direct and indirect effects of grazing on silica dynamics in grasses; this may be especially true for grass species growing in the Serengeti plains, which have a long co-evolutionary history with herbivores. Large-bodied grazers compact soils, resulting in increased bulk density (e.g., Bakker et al., 2004; Holdo and Mack, 2014; Veldhuis et al., 2014) and matric water potential and, thus, alter the ability of roots to absorb water. While manual defoliation studies yield information about certain physiological responses, the literature review presented here suggests that this approach may not properly mimic the complex physiological responses associated with natural grazing, some of which may result from indirect effects associated with modification of soil water (see below). In summary, plants perceive herbivore effects through a suite of signals, some of which, such as changes in the abiotic environment, are not elicited directly by the removal of tissues.

\section{WATER AND COLLECTION SITE EFFECTS}

Themeda individuals in the high water treatment accumulated significantly greater foliar silica than those in the ambient water group (Figure 2), but this trend was not observed for Digitaria. This suggests either differential silica uptake mechanisms of the two species or different generalized physiological responses to drought which indirectly influence silica accumulation. Since Themeda responded to changes in water availability, we hypothesize that active uptake mechanisms are present in this species which allow it to increase uptake of $\mathrm{Si}(\mathrm{OH})_{4}$ from the soil solution when water is abundant. If true, this then raises the question, why would Digitaria not also increase uptake of a ubiquitously beneficial element under similar conditions? One possible explanation is that the different life histories of these two species, coupled with the proposed costs of silica accumulation (Cooke and Leishman, 2012) have resulted in selection for differential silica uptake mechanisms, in which tall, bunch species but not short, lawn species, have incorporated active Si uptake mechanisms such as the use of specialized energy-dependent transport molecules. Digitaria has highly flexible leaves which are capable of curling under drought conditions to prevent transpiration; this drought tolerance mechanism would likely be hindered due to the loss of bulliform cell function associated with leaf tissue silicification (Honaine and Osterrieth, 2011). Conversely, the benefit of improved drought tolerance associated with silica accumulation (Gao etal., 2006; Eneji et al., 2008) is likely of greater relative importance for bunch grass species, such as Themeda, which experience intense light competition and a significant seasonal water deficit. Increased silica uptake under high water availability may serve to buffer bunch grasses against future drought events while simultaneously producing an erect canopy structure (see Isa et al., 2010) for light competition and offsetting carbon costs. Under this proposed hypothesis, that bunch grasses benefit more than lawn grasses due to more intense light competition, any anti-herbivore benefits are secondary to the direct adaptive significance of silica accumulation, which is related to water and/or light limitation

Consistent with the observed effects of watering treatments, the silica differences among collection sites also indicate that water availability may be an important determinant of grass foliar silica content. Themeda individuals collected from high rainfall sites KCW and MSB, where light competition is expected to be more intense, exhibited significantly greater silica content than individuals collected from the low rainfall site TOG, where light competition is expected to be less intense. In contrast, the leaf silica content of Digitaria individuals was not influenced by collection site (Figure 3). This observation reinforces the notion that water strongly influences foliar silica content of grasses and implies a pattern of increasing silica content of tall bunch grass species, like Themeda, with increasing distance from the plains and increasing light competition.

Other possible explanations exist for the observed site-level variation in silica content of T. triandra. Numerous fertilization studies have indicated that plant silica content is strongly correlated with availability of $\mathrm{Si}(\mathrm{OH})_{4}$ in the soil medium (Fox et al., 1969; Jones and Handreck, 1969; Van der Vorm, 1980; Gali and Smith, 1992), and more recently, ecological studies have demonstrated a similar relationship between soils and plants in natural systems. Biogenic silica content of grasses in a South African savanna was higher for plants collected from basaltic soils than for those collected from granitic soils, reflecting differences in weatherability and dissolved silica (DSi) content of these contrasting parent materials (Melzer et al., 2011). Cooke and Leishman (2012) compared foliar silica content of plant communities from Hawkesbury sandstone and a nearby diatreme forest with nearly three times as much plant available soil Si; though not statistically significant, they observed a general trend of higher foliar silica content for plants from the diatreme site, including a fivefold difference in leaf silica observed for the sedge Schoenus melanostachys. The unique nature of the silica-depleted carbonatite ash that enriches the Serengeti plains may contribute to a gradient in available soil $\mathrm{Si}$, in which available $\mathrm{Si}$ increases toward the northern and western corridors of the park. However, more work is needed to document how soil Si availability varies within SNP and how it may interact with gradients in soil moisture, $\mathrm{pH}$, and other important soil nutrients known to vary across the landscape (de Wit, 1978; Jager, 1982). Finally, we caution that, due to geographic separation, plant genotype should also vary among sites (Soininen et al., 2013), and we cannot rule out genotypic variation as an important influence on silica accumulation patterns.

\section{ECOLOGICAL AND EVOLUTIONARY IMPLICATIONS}

The results of our literature review suggest that induced silica response to defoliation is dynamic and dependent upon interactions with additional biotic and abiotic factors. For example, defoliation by burning resulted in more than a $1 / 3$ decrease in silica content of Aristida grass (Dufek et al., 2014). Moreover, seasonal (Georgiadis and McNaughton, 1988, 1990; Carey and Fulweiler, 2013; Struyf et al., 2005) and inter-annual (Morton and Jutras, 1974; Pahkala and Pihala, 2000) variations in field measurements of grass silica content indicate that leaf tissue silicification is highly plastic. While seasonal fluctuations in grass silica content are welldocumented, it remains unclear whether dynamic silica values measured in the field occur in response to changes in grazing intensity, temperature, precipitation, or, most likely, a complex interaction among these stochastic variables. 
Silica accumulation is considered a central axis of grass-grazer coevolution throughout the literature, often cited as a driving force behind the evolution of hypsodonty and the coupled taxonomic radiation of grasses and grazers (Mendoza and Palmqvist, 2008; Hummel et al., 2011). The evolution of large-bodied mammalian grazers is thought to have selected for specialized traits of the Poaceae such as meristematic growth from a well-protected crown, rapid growth rate, and high levels of Si accumulation (McNaughton, 1979; Coughenour, 1985). Likewise, these plant traits are thought to have influenced herbivore dentition, digestion, and behavior (McNaughton, 1984; Massey and Hartley, 2006; Erickson etal., 2012). Our study and literature review, however, suggest that the evolutionary significance of silica accumulation may be a remnant of tradeoffs associated with the leaf economic spectrum that resulted in the evolution of two contrasting grass functional types. Silica accumulation may have first served to improve drought tolerance with herbivore deterrence as a secondary role. Fossil data support this notion: grassdominated habitats preceded the appearance of North American and Mediterranean grazing specialists (Strömberg, 2006; Strömberg etal., 2007), and an investigation of the Gran Barranca fossil record indicates that open grass habitats were not necessary pre-conditions for favoring early hypsodont mammals in Earth's earliest grass-dominated systems (Strömberg et al., 2013).

\section{ACKNOWLEDGMENTS}

The authors thank Dr. George Donati of WFU for assistance with ICP measurements of silica. We also thank the Serengeti Wildlife Research Centre, Tanzania Wildlife Research Institute, Tanzania National Parks, and the management of Serengeti National Park for their help during our experiments. We offer a special thanks to Emilian P. Mayemba for helping with the construction of the plot exclosures and to Peter M. Ezra for assistance with the common garden study. Financial support for this project was supported in part by an Early Career Project Grant from the British Ecological Society (UK) to T. M. Anderson and grant DEB-1145861 from the National Science Foundation (USA) to T. M. Anderson.

\section{SUPPLEMENTARY MATERIAL}

The Supplementary Material for this article can be found online at: http://www.frontiersin.org/journal/10.3389/fpls.2014.00568/ abstract

Table S1 | Results from linear mixed model in R testing for interactions between species and water on foliar silica accumulation. Block was included as a random effect. $P$ values in bold indicate significance at $\alpha=0.05$.

Table S2 | Summary of studies included in literature review of induced silica response of Poaceae; colors in the "Defoliation Response" column correspond with Figure 4. In the Defoliation Response column, "0" indicates that a species exhibited less than a $20 \%$ relative change in foliar silica content in response to defoliation, while " + " indicates a $\geq 20 \%$ increase in silica, and a " -" indicates $a \geq 20 \%$ decrease in silica.

\section{REFERENCES}

Agarie, S., Hanaoka, N., Ueno, O., Miyazaki, A., Kubota, F., Agata, W., et al. (1998). Effects of silicon on tolerance to water deficit and heat stress in rice plants, monitored by electrolyte leakage. Plant Prod. Sci. 1, 96-103. doi: 10.1626/ pps.1.96

Agrawal, A. A., and Rutter, M. T. (1998). Dynamic anti-herbivore defense in antplants: the role of induced responses. Oikos 83, 227-236. doi: 10.2307/3546834
Anderson, G. D., and Talbot, L. M. (1965). Soil factors affecting the distribution of the grassland types and their utilization by wild animals on the serengeti plains, tanganyika. J. Ecol. 53, 33-56. doi: 10.2307/2257564

Anderson, T. M., Hopcraft, J. G., Eby, S., Ritchie, M., Grace, J. B., and Olff, H. (2010). Landscape-scale analyses suggest both nutrient and antipredator advantages to serengeti herbivore hotspots. Ecology 91, 1519-1529. doi: 10.1890/09-0739.1

Anderson, T. M., Kumordzi, B. B., Fokkema, W., Fox, H. V., and Olff, H. (2013). Distinct physiological responses underlie defoliation tolerance in african lawn and bunch grasses. Int. J. Plant Sci. 174, 769-778. doi: 10.1086/670237

Anderson, T. M., Ritchie, M. E., and McNaughton, S. J. (2007). Rainfall and soils modify plant community response to grazing in serengeti national park. Ecology 88, 1191-1201. doi: 10.1890/06-0399

Anderson, T. M., Schütz, M., and Risch, A. C. (2012). Seed germination cues and the importance of the soil seed bank across an environmental gradient in the Serengeti. Oikos 121, 306-312. doi: 10.1111/j.1600-0706.2011.19803.x

Ando, H., Kakuda, K., Fujii, H., Suzuki, K., and Ajiki. T. (2002). Growth and canopy structure of rice plants grown under field conditions as affected by $\mathrm{Si}$ application growth and canopy structure of rice plants grown under field conditions as affected by Si application. Soil Sci. Plant Nutr. 48, 429-432. doi: 10.1080/00380768.2002.10409221

Arimura, G., Ozawa, R., Shimoda, T., Nishioka, T., Boland, W., and Takabayashi, J. (2000). Herbivory-induced volatiles elicit defence genes in lima bean leaves. Nature 406, 512-515. doi: 10.1038/35020072

Bakker, E. S., Olff, H., Boekhoff, M., Gleichman, J. M., and Berendse, F. (2004). Impact of herbivores on nitrogen cycling: contrasting effects of small and large species. Oecologia 138, 91-101. doi: 10.1007/s00442-003-1402-5

Banuelos, M. J., and Obeso, J. R. (2000). Effect of grazing history, experimental defoliation, and genotype on patterns of silicification in agrostis tenuis sibth. Ecoscience 7, 45-50.

Bates, D., Maechler, M., Bolker, B., and Walker, S. (2014). _lme4: Linear MixedEffects Models using Eigen and S4_. R Package Version 1.1-7. Available at: https:/github.com/lme4/lme4/; http://lme4.r-forge.r-project.org/

Brizuela, M. A., and Detling, J. K. (1986). Silicon concentration of grasses growing in sites with different grazing histories. Ecology 67, 1098-1101. doi: 10.2307/1939834

Carey, J. C., and Fulweiler, R. W. (2013). Nitrogen enrichment increases net silica accumulation in a temperate salt marsh. Limnol. Oceanogr. 58, 99-111. doi: 10.4319/lo.2013.58.1.0099

Cid, M. S., Detling, J. K., Whicker, A. D., and Brizuela, M. A. (1990). Silicon uptake and distribution in agropyron smithii as related to grazing history and defoliation. J. Range Manag. 43, 344-346. doi: 10.2307/3898929

Cooke, J., and Leishman, M. R. (2011a). Is plant ecology more siliceous than we realise? Trends Plant Sci. 16, 61-68. doi: 10.1016/j.tplants.2010.10.003

Cooke, J., and Leishman, M. R. (2011b). Silicon concentration and leaf longevity: is silicon a player in the leaf dry mass spectrum? Funct. Ecol. 25, 1181-1188. doi: 10.1111/j.1365-2435.2011.01880.x

Cooke, J., and Leishman, M. R. (2012). Tradeoffs between foliar silicon and carbonbased defences: evidence from vegetation communities of contrasting soil types. Oikos 121, 2052-2060. doi: 10.1111/j.1600-0706.2012.20057.x

Cotterill, J. V., Watkins, R. W., Brennon, C. B., and Cowan, D. P. (2007). Boosting silica levels in wheat leaves reduces grazing by rabbits. Pest Manag. Sci. 63, 247253.

Coughenour, M. B. (1985). Graminoid responses to grazing by large herbivores: adaptations, exaptations, and interacting processes. Ann. Mo. Bot. Gar. 72, 852863. doi: $10.2307 / 2399227$

Cromsigt, J. P. G. M., and Olff, H. (2008). Dynamics of grazing lawn formation: an experimental test of the role of scale-dependent processes. Oikos 117, 1444-1452. doi: 10.1111/j.2008.0030-1299.16651.x

de Wit, H. A. (1978). Soils and Grassland Types of the Serengeti Plain Tanzania. Ph.D. dissertation, Agricultural University, Wageningen.

Diaz, S., and Cabido, M. (1997). Plant functional types and ecosystem function in relation to global change. J. Veg. Sci. 8, 463-474. doi: 10.1111/j.16541103.1997.tb00842.x

Dufek, N. A., Vermeire, L. T., Waterman, R. C., and Ganguli, A. C. (2014). t fire and nitrogen addition increase forage quality of aristida purpurea. Rang. Ecol. Manag. 67, 298-306. doi: 10.2111/REM-D-13-00057.1

Elliott, C. L., and Snyder, G. H. (1991). Autoclave-induced digestion for the colorimetric determination of silicon in rice straw. J. Agric. Food Chem. 39, 1118-1119. doi: 10.1021/jf00006a024 
Endara, M., and Coley, P. D. (2011). The resource availability hypothesis revisited: a meta-analysis. Funct. Ecol. 25, 389-398. doi: 10.1111/j.1365-2435.2010. 01803.x

Eneji, A. E., Inanaga, S., Muranaka, S., Li, J., Hattori, T., An, P., et al. (2008). Growth and nutrient use in four grasses under drought stress as mediated by silicon fertilizers. J. Plant Nutr. 31, 355-365. doi: 10.1080/01904160801 894913

Epstein, E. (1999). Silicon. Annu. Rev. Plant Physiol. Plant Mol. Biol. 50, 641-664. doi: 10.1146/annurev.arplant.50.1.641

Erickson, G. M., Krick, B. A., Hamilton, M., Bourne, G. R., Norell, M. A., Lilleodden, E., et al. (2012). Complex dental structure and wear biomechanics in hadrosaurid dinosaurs. Science 338, 98-101. doi: 10.1126/science.1224495

Fauteux, F., Chain, F., Belzile, F., Menzies, J. G., and Bélanger, R. R. (2006). The protective role of silicon in the arabidopsis-powdery mildew pathosystem. Proc. Natl. Acad. Sci. U.S.A. 103, 17554-17559 doi: 10.1073/pnas.0606330103

Feeny, P. (1976). "Plant apparency and chemical defense," in Biochemical Interaction Between Plants and Insects, ed. J. W. Wallace (New York: Plenum Press), 1-40. doi 10.1007/978-1-4684-2646-5_1

Fox, R. L., Silva, J. A., Plucknett, D. L., and Teranishi, D. Y. (1969). Soluble and total silicon in sugar cane. Plant Soil 30, 81-92. doi: 10.1007/BF01885263

Fynn, R., Morris, C., Ward, D., and Kirkman, K. (2011). Trait-environment relations for dominant grasses in south african mesic grassland support a general leaf economic model. J. Veg. Sci. 22, 528-540. doi: 10.1111/j.1654-1103.2011. 01268.x

Gali, H. U., and Smith, C. C. (1992). Effect of silicon supply on growth, fertility, and mineral composition of an annual brome, bromus secalinus L. (Gramineae). Am J. Bot. 79, 1259-1263. doi: 10.2307/2445053

Gali-Muhtasib, H. U., Smith, C. C., and Higgins, J. J. (1992). The effect of silica in grasses on the feeding behavior of the prairie vole, microtus ochrogaster author. Ecology 73, 1724-1729. doi: 10.2307/1940024

Galvez, L., Clark, R. B., Gourley, L. M., and Maranville, J. W. (1987). Silicon interactions with manganese and aluminum toxicity in sorghum. J. Plant Nutr. 10, 1139-1147. doi: 10.1080/01904168709363642

Gao, X., Zou, C., Wang, L., and Zhang, F. (2006). Silicon decreases transpiration rate and conductance from stomata of maize plants. J. Plant Nutr. 29, 1637-1647. doi: 10.1080/01904160600851494

Georgiadis, N. J., and McNaughton, S. J. (1988). Interactions between grazers and a cyanogenic grass, cynodon plectostachyus. Oikos 51, 343-350. doi: $10.2307 / 3565316$

Georgiadis, N. J., and McNaughton, S. J. (1990). Elemental and fibre contents of savanna grasses: variation with grazing, soil type, season, and species. J. Appl. Ecol. 27, 623-634. doi: 10.2307/2404307

Gibson, D. J. (2009). Grasses and Grassland Ecology. New York, NY: Oxford University Press.

Gittins, J. (1998). Differentiation of natrocarbonatite magma at oldoinyo lengai volcano, tanzania. Mineral. Mag. 62, 759-768. doi: 10.1180/0026461985 48142

Heine, G., Tikum, G., and Horst, W. J. (2007). The effect of silicon on the infection by and spread of pythium aphanidermatum in single roots of tomato and bitter gourd. J. Exp. Bot. 58, 569-577. doi: 10.1093/jxb/erl232

Hodson, M. J., White, P. J., Mead, A., and Broadley, M. R. (2005). Phylogenetic variation in the silicon composition of plants. Ann. Bot. 96, 1027-1046. doi: 10.1093/aob/mci255

Holdo, R. M., Holt, R. D., and Fryxell, J. M. (2009). Opposing rainfall and plant nutritional gradients best explain the wildebeest migration in the serengeti. Am. Nat. 173, 431-445. doi: 10.1086/597229

Holdo, R. M., and Mack, M. C. (2014). Functional attributes of savanna soils: contrasting effects of tree canopies and herbivores on bulk density, nutrients and moisture dynamics. J. Ecol. 102, 1171-1182. doi: 10.1111/1365-2745.12290

Honaine, M. F., and Osterrieth, M. L. (2011). Silicification of the adaxial epidermis of leaves of a panicoid grass in relation to leaf position and section and environmental conditions. Plant Biol. 14, 596-604. doi: 10.1111/j.1438-8677.2011.00530.x

Hothorn, T., Bretz, F., and Westfall, P. (2008). Simultaneous inference in general parametric models. Biom. J. 50, 346-363. doi: 10.1002/bimj.200810425

Hummel, J., Findeisen, E., Südekum, K., Ruf, I., Kaiser, T. M., Bucher, M., et al. (2011). Another one bites the dust: faecal silica levels in large herbivores correlate with high-crowned teeth. Proc. R. Soc. B Biol. Sci. 278, 1742-1747. doi: $10.1098 /$ rspb.2010.1939
Isa, M., Bai, S., Yokoyama, T., Feng Ma, J., Ishibashi, Y., Yuasa, T., et al. (2010). Silicon enhances growth independent of silica deposition in a low-silica rice mutant, lsil. Plant Soil 331, 361-375. doi: 10.1007/s11104-009-0258-9

Jager, T. J. (1982). Soils of the Serengeti Woodlands, Wageningen.

Jones, L. H. P., and Handreck, K. A. (1969). Uptake of silica by trifolium incarnatum in relation to the concentration in the external solution and to transpiration. Plant Soil 1, 71-80. doi: 10.1007/BF01885262

Keller, J., Klaudius, J., Kervyn, M., Ernst, G. G. J., and Mattsson, H. B. (2010). Fundamental changes in the activity of the natrocarbonatite volcano oldoinyo lengai, tanzania. Bull. Volcanol. 72, 893-912. doi: 10.1007/s00445-010-0371-x

Kraska, J. E., and Breitenbeck, G. A. (2010). Simple, robust method for quantifying silicon in plant tissue. Commun. Soil Sci. Plant Anal. 41, 2075-2085. doi: 10.1080/00103624.2010.498537

Ma, J. F., Tamai, K., Yamaji, N., Mitani, N., Konishi, S., Katsuhara, M., et al. (2006). A silicon transporter in rice. Nature 440, 688-691. doi: 10.1038/nature04590

Ma, J. F., and Yamaji, N. (2006). Silicon uptake and accumulation in higher plants. Trends Plant Sci. 11, 392-397. doi: 10.1016/j.tplants.2006.06.007

Ma, J. F., Yamaji, N., Mitani, N., Tamai, K., Konishi, S., Fujiwara, T., et al. (2007). An efflux transporter of silicon in rice. Nature 448, 209-212. doi: 10.1038 /nature05964

Massey, F. P., Ennos, A. R., and Hartley, S. E. (2007). Herbivore specific induction of silica-based plant defences. Oecologia 152, 677-683. doi: 10.1007/s00442-0070703-5

Massey, F. P., and Hartley, S. E. (2006). Experimental demonstration of the antiherbivore effects of silica in grasses: impacts on foliage digestibility and vole growth rates. Proc. R. Soc. B Biol. Sci. 273, 2299-2304. doi: 10.1098/rspb.2006.3586

Massey, F. P., and Hartley, S. E. (2009). Physical defences wear you down: progressive and irreversible impacts of silica on insect herbivores. J. Anim. Ecol. 78, 281-291. doi: 10.1111/j.1365-2656.2008.01472.x

Mauricio, R., Rausher, M. D., and Burdick, D. S. (1997). Variation in the defense strategies of plants: are resistance and tolerance mutually exclusive? Ecology 78, 1301-1311. doi: 10.1890/0012-9658(1997)078[1301:VITDSO]2. $0 . \mathrm{CO} ; 2$

McNaughton, S. J. (1979). Grazing as an optimization process: grass-ungulate relationships in the serengeti. Am. Nat. 113, 691-703. doi: 10.1086/283426

McNaughton, S. J. (1984). Grazing lawns: animals in herds, plant form, and coevolution. Am. Nat. 124, 863-886. doi: 10.1086/284321

McNaughton, S. J., and Tarrants, J. L. (1983). Grass leaf silicification: natural selection for an inducible defense against herbivores. Proc. Natl. Acad. Sci. U.S.A. 80, 790-791. doi: 10.1073/pnas.80.3.790

McNaughton, S. J., Tarrants, J. L., McNaughton, M. M., and Davis, R. H. (1985). Silica as a defense against herbivory and a growth promotor in african grasses. Ecology 66, 528-535. doi: 10.2307/1940401

Melzer, S. E., Chadwick, O. A., Hartshorn, A. S., Khomo, L. M., Knapp, A. K., and Kelly, E. F. (2011). Lithologic controls on biogenic silica cycling in South African savanna ecosystems. Biogeochemistry 108, 317-334. doi: 10.1007/s10533011-9602-2

Melzer, S. E., Knapp, A. K., Kirkman, K. P., Smith, M. D., Blair, J. M., and Kelly, E. F. (2009). Fire and grazing impacts on silica production and storage in grass dominated ecosystems. Biogeochemistry 97, 263-278. doi: 10.1007/s10533-0099371-3

Mendoza, M., and Palmqvist, P. (2008). Hypsodonty in ungulates: an adaptation for grass consumption or for foraging in open habitat? J. Zool. 274, 134-142. doi: 10.1111/j.1469-7998.2007.00365.x

Mitani, N., Yamaji, N., and Feng Ma, J. (2009). Identification of maize silicon influx ransporters. Plant Cell Physiol. 50, 5-12. doi: 10.1093/pcp/pcn110

Morton, B. B., and Jutras, M. W. (1974). Silica concentrations in grazed and ungrazed forage species. Agron. J. 66, 10-12. doi: 10.2134/agronj1974.0002196200660 $0010003 \mathrm{x}$

Oyarzabal, M., and Oesterheld, M. (2009). Phosphorus reserves increase grass regrowth after defoliation. Oecologia 159, 717-724. doi: 10.1007/s00442-0081263-z

Pahkala, K., and Pihala, M. (2000). Different plant parts as raw material for fuel and pulp production. Ind. Crops Prod. 11, 119-128. doi: 10.1016/S09266690(99)00050-3

Piperno, D. R., and Pearsall, D. M. (1998). The silica bodies of tropical american grasses: morphology, taxonomy, and implications for grass systematics and fossil phytolith identification. Library 85, 1-40. 
Prasad, V., Strömberg, C. A. E., Alimohammadian, H., and Sahni, A. (2005). Dinosaur coprolites and the early evolution of grasses and grazers. Science 310, 1177-1180. doi: 10.1126/science.1118806

Querné, J., Ragueneau, O., and Poupart, N. (2012). In situ biogenic silica variations in the invasive salt marsh plant, spartina alterniflora: a possible link with environmental stress. Plant Soil 352, 157-171. doi: 10.1007/s11104-011-0986-5

R Development Core Team. (2014). R: A Language and Environment for Statistical Computing, R Foundation for Statistical Computing, Vienna. Available at: http://www.R-project.org/

Raven, J. A. (1983). The transport and function of silicon in plants. Biol. Rev. Cambridge Philisophical Society 58, 179-207. doi: 10.1111/j.1469185X.1983.tb00385.x

Reynolds, J. J., Lambin, X., Massey, F. P., Reidinger, S., Sherratt, J. A., Smith, M. J., et al. (2012). Delayed induced silica defences in grasses and their potential for destabilising herbivore population dynamics. Oecologia 170, 445-456. doi: 10.1007/s00442-012-2326-8

Rudall, P. J., Prychid, C. J., and Gregory, T. (2014). Epidermal patterning and silica phytoliths in grasses: an evolutionary history. Bot. Rev. 80, 59-71. doi: 10.1007/s12229-014-9133-3

Sangster, A. G., Hodson, M. J., and Tubb, H. J. (2001). "Silicon deposition in higher plants," in Silicon in Agriculture, eds L. E. Datnoff, G. H. Snyder, and G. H. Korndorfer (New York: Elsevier), 85-113. doi: 10.1016/S0928-3420(01)80009-4

Sangster, A. G., and Parry, D. W. (1970). Silica deposition in the grass leaf in relation to transpiration and the effect of dinitrophenol. Ann. Bot. 35, 667-677.

Sanson, G. D., Kerr, S. A., and Gross, K. A. (2007). Do silica phytoliths eally wear mammalian teeth? J. Archaeol. Sci. 34, 526-531. doi: 10.1016/j.jas.2006.06.009

Schaller, J., Brackhage, C., and Dudel, E. G. (2012). Silicon availability changes structural carbon ratio and phenol content of grasses. Environ. Exp. Bot. 77, 283-287. doi: 10.1016/j.envexpbot.2011.12.009

Sinclair, A. R. E., and Norton-Griffiths, M. (1979). Serengeti: Dynamics of an Ecosystem. Chicago, IL: University of Chicago Press.

Soininen, E. M., Bråthen, K. A., Jusdado, J. G. H., Reidinger, S., and Hartley, S. E. (2013). More than herbivory: levels of silica-based defences in grasses vary with plant species, genotype and location. Oikos 122, 30-41. doi: 10.1111/j.16000706.2012.20689.x

Stebbins, G. L. (1972). "The evolution of the grass family," in The Biology and Utilization of Grasses, eds V. B. Youngner and C. M. McKell (New York: Academic Press).

Street, J. R. (1974). The Influence of Silica Concentration on the Chemical Composition and Decomposition Rates of Turfgrass Tissue and Water Absorption Rates among Three Turfgrass Species. Ohio State University.

Strömberg, C. A. E. (2006). Evolution of hypsodonty in equids: testing a hypothesis of adaptation. Paleobiology 32, 236-258. doi: 10.1666/00948373(2006)32[236:EOHIET]2.0.CO;2
Strömberg, C. A. E. (2011). Evolution of grasses and grassland ecosystems. Annu. Rev. Earth Planet. Sci. 39, 517-544. doi: 10.1146/annurev-earth-040809152402

Strömberg, C. A. E., Dunn, R. E., Madden, R. H., Kohn, M. J., and Carlini, A. A. (2013). Decoupling the spread of grasslands from the evolution of grazertype herbivores in South America. Nat. Commun. 4, 1478. doi: 10.1038/ ncomms 2508

Strömberg, C. A. E., Werdelin, L., Friis, E. M., and Saraç, G. (2007). The spread of grass-dominated habitats in turkey and surrounding areas during the cenozoic: phytolith evidence. Palaeogeogr. Palaeoclimatol. Palaeoecol. 250, 18-49. doi: 10.1016/j.palaeo.2007.02.012

Struyf, E., Van Damme, S., Gribsholt, B., and Meire, P. (2005). Freshwater marshes as dissolved silica recyclers in an estuarine environment (Schelde Estuary, Belgium). Hydrobiologia 540, 69-77. doi: 10.1007/s10750-004-7104-0

Van der Vorm, P. D. J. (1980). Uptake of Si by five plant species, as influenced by variations in Si-supply. Plant Soil 56, 153-156. doi: 10.1007/BF02197962

Veldhuis, M. P., Howison, R. A., Fokkema, R. W., Tielens, E., and Olff, H. (2014). A novel mechanism for grazing lawn formation: large herbivore-induced modification of the plant-soil water balance. J. Ecol. doi: 10.1111/1365-2745.12322

White, F. (1983). The Vegetation of Africa. Paris: UNESCO.

Wright, I. J., Reich, P. B., Westoby, M., Ackerly, D. D., Baruch, Z., Bongers, F., et al. (2004). The worldwide leaf economics spectrum. Nature 428, 821-827. doi: 10.1038 /nature 02403

Zhu, Z., Wei, G., Li, J., Qian, Q., and Yu, J. (2004). Silicon alleviates salt stress and increases antioxidant enzymes activity in leaves of salt-stressed cucumber (Cucumis Sativus L.). Plant Sci. 167, 527-533. doi: 10.1016/j.plantsci.2004. 04.020

Conflict of Interest Statement: The authors declare that the research was conducted in the absence of any commercial or financial relationships that could be construed as a potential conflict of interest.

Received: 04 June 2014; accepted: 02 October 2014; published online: 21 October 2014. Citation: Quigley KM and Anderson TM (2014) Leaf silica concentration in Serengeti grasses increases with watering but not clipping: insights from a common garden study and literature review. Front. Plant Sci. 5:568. doi: 10.3389/fpls.2014.00568

This article was submitted to Functional Plant Ecology, a section of the journal Frontiers in Plant Science.

Copyright (C) 2014 Quigley and Anderson. This is an open-access article distributed under the terms of the Creative Commons Attribution License (CC BY). The use, distribution or reproduction in other forums is permitted, provided the original author(s) or licensor are credited and that the original publication in this journal is cited, in accordance with accepted academic practice. No use, distribution or reproduction is permitted which does not comply with these terms. 